\title{
Control of the geomorphology and gas hydrate extent on widespread gas emissions offshore Romania
}

\section{La géomorphologie des fonds marins et la présence d'hydrates de gaz contrôlent les émissions de gaz dans la Mer Noire au large de la Roumanie}

\author{
Riboulot Vincent ${ }^{1,{ }^{*}}$, Cattaneo Antonio ${ }^{1}$, Scalabrin Carla ${ }^{1}$, Gaillot Arnaud ${ }^{1}$, Jouet Gwenael ${ }^{1}$, \\ Ballas Gregory ${ }^{1}$, Marsset Tania ${ }^{1}$, Garziglia Sebastien ${ }^{1}$, Ker Stephan ${ }^{1}$ \\ ${ }^{1}$ IFREMER, Ctr Brest, Inst CARNOT EDROME, Geosci Marines, F-29280 Plouzane, France. \\ *Corresponding author : Vincent Riboulot, email address : riboulot@ifremer.fr
}

\begin{abstract}
:
The Romanian sector of the Black Sea deserves attention because the Danube deep-sea fan is one of the largest sediment depositional systems worldwide and is considered the world's most isolated sea, the largest anoxic water body on the planet and a unique energy-rich sea. Due to the high sediment accumulation rate, presence of organic matter and anoxic conditions, the Black sea sediments offshore the Danube delta is rich in gas and thus shows Bottom Simulating Reflectors (BSR). The cartography of the BSR over the last 20 years, exhibits its widespread occurrence, indicative of extensive development of hydrate accumulations and a huge gas hydrate potential. By combining old and new datasets acquired in 2015 during the GHASS expedition, we performed a geomorphological analysis of the continental slope north-east of the Danube canyon compared with the spatial distribution of gas seeps in the water column and the predicted extent of the gas hydrate stability zone. This analysis provides new evidence of the role of geomorphological setting and gas hydrate extent in controlling the location of the observed gas expulsions and gas flares in the water column. Gas flares are today considered an important source of the carbon budget of the oceans and, potentially, of the atmosphere.
\end{abstract}

\section{Résumé}

Le secteur roumain de la Mer Noire est dominé par la présence du canyon du Danube et d'un des plus grands systèmes de dépôts de sédiment du monde. La Mer Noire est considérée comme la plus grande mer isolée du monde, la plus grande masse d'eau anoxique de la planète et une mer riche en énergie 
fossile. En raison d'un taux de sédimentation élevé, de la présence d'une grande quantité de matière organique et des conditions anoxiques, les sédiments de Mer Noire situés au large du delta du Danube sont riches en gaz et l'étude de données de sismique réflexion montre la présence d'un réflecteur sismique particulier appelé communément «Bottom Simulating Reflector ou BSR » qui marque la base de stabilité des hydrates de gaz. La cartographie du BSR au cours des 20 dernières années montre que les hydrates de gaz se seraient accumulés sur de vastes zones géographiques et que le secteur roumain de la Mer Noire a un fort potentiel d'hydrate de gaz. En combinant les anciens et les nouveaux jeux de données acquis en 2015 lors de la campagne océanographique GHASS, nous avons réalisé (1) une analyse géomorphologique de la pente continentale au nord-est du canyon du Danube, (2) une cartographie des panaches de gaz acoustiquement détectés dans la colonne d'eau et (3) le calcul et la cartographie de la zone de stabilité des hydrates de gaz. La comparaison de ces résultats fournit de nouvelles preuves du rôle de la géomorphologie et de la présence des hydrates de gaz sur la migration du gaz libre et la localisation des panaches de gaz dans la colonne d'eau. L'expulsion de gaz dans la mer est aujourd'hui considérée comme une source importante alimentant le budget carbone des océans et, potentiellement, de l'atmosphère.

Keywords : gas hydrates, free gas, gas flares, BSR, Black Sea, geomorphology

Mots clés : hydrates de gaz / gaz libre / panaches de gaz / BSR / Mer Noire / géomorphologie 


\section{1. Introduction}

22 The Black Sea is considered as the world's most isolated sea, the largest anoxic water body on the planet 23 and a unique energy-rich sea (Overmann and Manske, 2006). $\mathrm{CH}_{4}$ seepage is extremely intense on the shelf 24 and on the slope of the Black Sea (Dimitrov, 2002; Mert Küçük et al.; Vassilev and Dimitrov, 2003), 25 especially along the Ukrainian (Greinert et al., 2010; Naudts et al., 2009; Naudts et al., 2008; Naudts et al., 26 2006) and Romanian margins (Popescu et al., 2007). Black Sea sediment abundantly contains GHs and $\mathrm{H}_{2} \mathrm{~S}$ 27 as $\mathrm{CH}_{4}$ and hydrogen source, respectively (Demirbas, 2009). GH occurrence in the Danube fan has been 28 known since the first hydrate discovery in shallow sub-bottom sediments at water depth of $1950 \mathrm{~m}$ in 1972 29 (Ginsburg, 1998; Yefremova and Zhizhchenko, 1974). Recently, the presence of GHs in deep sediments 30 was inferred from Bottom-Simulating Reflector (BSR) observations in the southern part of the Black Sea 31 fan (Ion et al., 2002) and in the northwestern Black Sea (Lüdmann et al., 2004; Zillmer et al., 2005). Multiple 32 BSRs occur on high-resolution reflection seismic data in the Danube deep-sea fan, associated with acoustic 
33 features indicating free gas (Popescu et al., 2006). The shallowest BSR in the Black Sea exhibits its

34 widespread occurrence, indicative of extensive development of hydrate accumulations and thus a huge gas

35 hydrate potential (Merey and Sinayuc, 2016). The origin of $\mathrm{CH}_{4}$ source for GHs is mainly biogenic (Hester

36 and Brewer, 2009), and formed during diagenesis stage in the evolution of organic materials within

37 sediment. $\mathrm{CH}_{4}$ forms sI type of $\mathrm{GH}$ at hydrate forming conditions (Sloan and Koh, 2007).

38 The Romanian margin is composed by a wide continental shelf and a slope incised by several submarine

39 canyons including the Danube canyon (Popescu et al., 2004). This canyon results from erosive sediment

40 flows which fed the Danube deep-sea fan, one of the most developed deep-sea sediment depositional

41 systems worldwide (Winguth et al., 2000; Wong et al., 1994), mainly during lowstand periods

42 (Constantinescu et al., 2015). During the Late Quaternary, the Black Sea and the Mediterranean experienced

43 several phases of connection and disconnection with relevant impact on the salinity of the Black Sea

44 oscillating between freshwater lake and salt-water sea conditions (Zubakov, 1988). Since the last phase

45 (9000 years ago), the Black Sea communicates with the Mediterranean Sea through the Bosphorus and

46 Dardanelle straits (Ross et al., 1970). So, the Black Sea which was a freshwater lake, has become a salt-

47 water sea. The salinity of the Black Sea reached its current value of $22 \mathrm{psu}$ at $2000 \mathrm{yr}$ cal BP (Soulet et

48 al., 2010). The Black Sea salinity is significant to appraise the extent of the Gas Hydrate Stability Zone

49 (GHSZ). Indeed, the thermodynamic stability of the GHs primarily depends on temperature, pressure, gas

50 composition and salinity (Sloan, 2003). GH deserve attention because their destabilization can provoke

51 seafloor instability (Crémière et al., 2016; Nisbet and Piper, 1998), and release significant quantities of gas

52 into the ocean, thus affecting gas inputs into the atmosphere (McGinnis et al., 2006; Solomon et al., 2009).

53 The study area, poorly known due to a lack of proper data resolution, is located in the Romanian sector of 54 the Black Sea, north-east of the Danube canyon. The aim of this paper is to improve the knowledge about:

55 (1) the seafloor morphology of the Romanian sector of the Black Sea, and (2) the influence of the 56 geomorphology and the GH occurrence in the distribution of gas flares acoustically detected in the water 57 column.

\section{Data and Method}

\subsection{Bathymetry and water column acoustic data}

60 The study is based on the analysis of bathymetry and water column acoustic data acquired during the 2015

61 GHASS cruise on board the R/V Pourquoi Pas ? (doi:10.17600/15000500). Ship-borne multibeam surveys

62 were conducted to map the external continental shelf and upper-mid slope adjacent to the Danube canyon

63 and to detect and locate the presence of free gas in the water column (Figs. 1, 2, 3). The acoustic data were

64 acquired with 1) a Reson seabat 7111 multibeam echo-sounder for shallow water from 5 to $500 \mathrm{~m}(100 \mathrm{kHz}$,

65301 beams, $1.8^{\circ} \times 1.5^{\circ}$ beam width, 0.17 to $3 \mathrm{~ms}$ pulse length, up to 20 pings per second), and 2) a Reson 


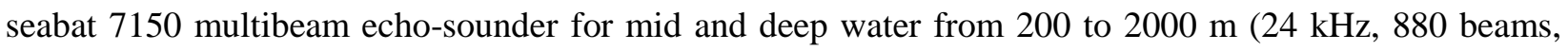
$0.5^{\circ} \times 0.5^{\circ}$ beam width, 2 to $15 \mathrm{~ms}$ pulse length, up to 15 pings per second). The shelf and upper slope were surveyed with both echo-sounders, while the deepest area was only surveyed by the Reson seabat 7150 . Bathymetric resolution of the whole study area is 20 metres. Water column processing was performed onboard with SonarScope and GLOBE softwares (C) Ifremer).

\subsection{High resolution seismic data}

High-resolution reflection seismic data were acquired during the 1998 BLASON (doi 10.17600/98020030) and 2002 BLASON2 (doi 10.17600/2020070) surveys of IFREMER and GeoEcoMar (Figs. 4, 5). Data were obtained using consecutively two seismic sources: a GI gun (central frequency $70 \mathrm{~Hz}$ ) and a mini GI gun (central frequency $150 \mathrm{~Hz}$ ). The receiver was a 24-channel streamer, $300 \mathrm{~m}$ long. Data were processed using Landmark's ProMAX software. The conventional processing flow included CDP gather formation, velocity analysis, removal of noisy traces, normal moveout correction and stack, migration, and seabed mute. No amplitude corrections were applied. Analysis and interpretation of seismic data were conducted using Seismic Microsystems' Kingdom Suite software.

\section{Results}

\subsection{Geomorphology}

\subsubsection{Margin physiography}

The continental shelf of the Romanian sector of the Black Sea has an average width of $160 \mathrm{~km}$ with a very subdued bathymetric gradient of $0.5^{\circ}$ in the outer shelf. The shelf edge occurs between 180 and $190 \mathrm{~m}$ water depth with a local slope angle of $4^{\circ}$ (Fig. 1). The continental slope has a regional slope of about $2^{\circ}$, but attains $4^{\circ}$ between 200 and $500 \mathrm{~m}$ water depth. In correspondence of some geological features such as pockmark and canyon flanks, the slope locally reaches $35^{\circ}$. The outer shelf and slope are incised by two canyons which could act as zones of confined sediment transport/bypass (Figs. 1,2). The upper slope shows many fluid expulsion features including pockmarks. The western part of the slope is affected by sediment gravity processes, while its central - eastern part by the presence of sediment wave fields and small mounts (Fig. 2).

\section{3.1.2. Canyons}

93 The two major canyons presented above have incised the $1200 \mathrm{~km}^{2}$ study area. In the $2.2 \mathrm{~km}$ wide Canyon 941 (Fig. 2), flank height reaches $160-110 \mathrm{~m}$ in the head with, locally, a slope angle of $15^{\circ}$. Canyon 1 head reaches the shelf at about $180 \mathrm{~m}$ of water depth. Canyon 1 is narrower downstream with a width of $1.5 \mathrm{~km}$ at around $1500 \mathrm{~m}$ water depth. A single well developed thalweg with axial incision, $350 \mathrm{~m}$ wide and $50 \mathrm{~m}$ high on average, is well developed with a mean height of $100 \mathrm{~m}$ and an average width of $700 \mathrm{~m}$ starting from $1200 \mathrm{~m}$ water depth. Canyon 1 is wider between 200 and $700 \mathrm{~m}$ water depth probably due to the effect 
99 of several submarine landslides (Fig. 2). Paradoxically, the slope value of the flanks, $15^{\circ}$ in the upper part

100 of the canyon, increases downstream to reach $25^{\circ}$ where the axial incision is the most developed.

101 Canyon 2, located to the east, is less incised than Canyon 1. It is $1.5 \mathrm{~km}$ wide. Its thalweg reaches $70 \mathrm{~m}$ in 102 the head with, locally, a $10^{\circ}$ flank slope. Further seaward, the height increases to reach $100 \mathrm{~m}$ with a $25^{\circ}$

103 flank slope. The axial incision, $15 \mathrm{~m}$ high, disappears at about $750 \mathrm{~m}$ of water depth (about $20 \mathrm{~km}$ from the 104 canyon head). Two other small canyons/gullies incise the upper slope northward of Canyon 2.

\section{$105 \quad$ 3.1.3. Mass transport Complexes}

106 The seafloor instabilities identified in the bathymetric map correspond to the morphologies of the headwall 107 scarps and lateral margins of the translational domain of the Mass Transport Complex (MTC) described in 108 Bull et al. (2009).They are observed between 200 and 900 m water depth, but most of them are detected 109 between 500 and $750 \mathrm{~m}$. Mainly on the both sides of the Canyon 1 (the scarp limits, in orange, are shown 110 in Fig. 2), we distinguish the destabilisations associated with the canyon from open slope scarps. All the 111 scarps disturb $20 \%$ of the surface of the seafloor of the study area. Their size is comprised between 1 and $11215 \mathrm{~km}^{2}$ with an average slope of $12^{\circ}$ that may locally reach $25^{\circ}$.

\section{3.1.4. Other seafloor features}

114 Some 50 pockmarks with diameters ranging from 100 to $150 \mathrm{~m}$ were detected at the seafloor in a region of $1153000 \mathrm{~km}^{2}$. The largest is $160 \mathrm{~m}$ wide and $9 \mathrm{~m}$ deep. The value of the slope of pockmark flanks is around $11610^{\circ}$, but it reaches up to $14^{\circ}$. Pockmarks were observed in the free gas area defined by Popescu et al. (2007), 117 in a water depth range of 175-475 m. All pockmarks have the same morphology as those first documented 118 in the literature (King and MacLean, 1970). They are mostly circular or oval in shape and have a conical or 119 dish-shaped vertical section. The $20 \mathrm{~m}$ resolution of the bathymetric data prevented the detection of small 120 pockmarks.

121 The central sector of the study area, between Canyons 1 and 2 at around 500-600 m water depth, is affected 122 by seafloor undulations originated by sediment transport and/or, less likely, by creeping processes (Fig. 2). 123 Some 63 sediment waves cover a region of $90 \mathrm{~km}^{2}$. The magnitude of the positive relief is around $2 \mathrm{~m}$.

124 Further seawards, numerous small mounts are detected between 700 and $1000 \mathrm{~m}$ water depth. The 140 125 mounts have an average diameter of $800 \mathrm{~m}$ and a positive relief of about $15 \mathrm{~m}$ with, locally, $12^{\circ}$ flank slope 126 (Fig. 2). The analysis of seismic profiles presented in Figure 5 suggests that the mounts are an inherited 127 morphology resulting from a compressive bulge of a landslide deposit buried under 35 mbsf. 


\subsubsection{Evidence of free gas in the water column}

130 We identified some 1409 gas seeps within the water column acoustic records (15 days acquisition during

131 GHASS cruise). The seepage activity does not appear homogenous, as the density of gas flares varies with

132 bathymetry and laterally. Many of the numerous and widespread gas flares that were recorded at the scale

133 of the Romanian sector of the Black Sea reach several hundreds of meters above the seafloor, attesting to a

134 vigorous seepage activity with high fluid fluxes (Fig. 3) and questioning about the fate of the gas in the

135 water column. Gas emissions may be particularly numerous within some sectors between $200 \mathrm{~m}$ and 800

$136 \mathrm{~m}$. No gas flares were detected in deeper areas. Gas emissions can be classified into 6 groups based on their

137 distribution and origin: (1) non-random gas seeps along the canyons/gullies; (2) non-random gas seeps along

138 headwall scarps and lateral margin of the MTC (Fig. 3C); (3) non-random gas seeps along fault/ crest line

139 (Fig. 3A); (4) non-random gas seeps at the landward termination of the GHSZ above small mounts; (5) non-

140 random gas seeps right above pockmark (Fig. 3B); and (6) other random gas seeps (Figs. 2, 7).

141 The maximum density of acoustic anomalies was found along the canyon path. The 606 gas seeps detected 142 at the break of slope of the canyon flanks represent $43 \%$ of the whole degassing sites. 495 gas seeps are 143 localized right above the scarps of the MTC, 116 around the faults identified on the outer shelf, 30 right 144 above the 50 pockmarks, 26 above a crest line at $750 \mathrm{mbsl}$ inside the GHSZ, and 81 in the sector of the 145 small mounts. Overall, $96 \%$ of the all gas seeps observed are above geomorphological structures: $78 \%$ are 146 right above escarpment induced by sedimentary destabilizations inside or outside canyons and $60 \%$ of the 147 pockmarks appear active. Only 4\% (55) of the gas seeps appear randomly distributed in the study area. 148 These gas seeps seem to be at location not affected by geomorphological structures.

\subsubsection{Evidence of free gas in seismic data}

150 The 2D HR seismic profiles show a relatively well preserved sedimentary stratification (Figs. 4, 5). Seismic 151 facies is dominated by high amplitude parallel seismic reflectors. From the shelf down to the slope, a MTC 152 is identified buried under $40 \mathrm{~m}$ of sediment. The source area of the MTC is delimited to the north in about $153200 \mathrm{~m}$ water depth by the shelf edge. The MTC is characterized by a transparent chaotic seismic facies. The 154 thickness of the mass deposit, about $20 \mathrm{~m}$ at $300 \mathrm{~m}$ water depth, progressively increases seawards to attain $15575 \mathrm{~m}$ at $700 \mathrm{~m}$ water depth. The thickness is not homogeneous and varies in function of the inherited relief 156 (Fig. 4B). The compressional domain of the MTC show many bulges draped by overlying sediment resulting 157 from the presence of small mounts at the seafloor.

158 Under the MTC, the seismic signature of sediment shows anomalies interpreted as the localized 159 accumulation of free gas (Figs. 4B, 4C). In marine sediments, free gas often yields anomalous seismic 160 signatures, making seismic methods a useful tool for the identification and characterization of the sub- 
seafloor gas charged body and the gas migrating system. Gas may appear as amplitude enhancement with an attenuation of the signal (Fig. 4) (Gay et al., 2007; Judd and Hovland, 1992; Netzeband et al., 2010). In

163 Figure 4 we interpret the upward bending reflections observed right under the MTC as corresponding to a 164 velocity pull-up artefact (Hustoft et al., 2007), and the inflection of seismic reflectors as corresponding to a 165 velocity pull-down effect (Hustoft et al., 2010). The amplitude enhancement of sedimentary layers (i.e., 166 "bright spots") under the MTC may occur when gas preferentially accumulates in highly permeable layers 167 (Riboulot et al., 2013; Taylor et al., 2000; Tréhu et al., 2004).

168 The disruption of seismic reflections often referred to as "acoustic turbidity" (Gay et al., 2007; Jones et al., 169 2010; Judd and Hovland, 1992; Mathys et al., 2005; Schroot et al., 2005), and/or as "disturbed zones" 170 (Schroot and Schuttenhelm, 2003) is observed right beneath the pockmarks above the MTC, where its 171 thickness is reduced (Figs. 4A, 4B). These anomalies can be caused by the presence of vertical gas chimneys 172 representing current migration of fluids in the sedimentary column (Heggland, 1997; Hempel et al., 1994). 173 Moreover, the lack of reflection in such vertical conduits may occur due to physical disruption of 174 sedimentary layering by migrating, gas-charged pore fluids (Davis, 1992; Gorman et al., 2002), or by highly175 reflective overlying interfaces that significantly reduce the transmission of energy (Garcia-Gil et al., 2002; Judd and Hovland, 1992).

\subsubsection{Evidence of gas hydrates in seismic data}

178 In the Romanian sector, BSR observation from conventional High Resolution (HR) seismic profiles, 179 acquired during the BLASON and BLASON2 cruises, provides indirect evidence of GH occurrence (Fig. 180 4). It represents the base of the GHSZ that appears as strong, negative-polarity, high-impedance seismic 181 reflections caused by free gas at the base of the phase boundary (Holbrook et al., 1996; Shipley et al., 1979). 182 The BSR in the study area is characterized by a distinct seismic reflection, sub-parallel to the seafloor, 183 showing reversed polarity, semi-continuous, crosscutting the sedimentary stratification and their position 184 can also be inferred on the basis of aligned amplitude terminations as Bangs et al. (2005) described offshore 185 Oregon (Fig. 5). Popescu et al. (2006) observed the same characteristics for multiple BSRs present in the 186 Danube sea-fan zone. The appearance of a strong impedance contrast at the location of the BSR with an 187 enhancement of the seismic reflection amplitude is an indication of the presence of gas beneath GHs (Dillon 188 and Paull, 1983; Paull et al., 1995). The absence of gas signature on seismic data over the BSR, presented 189 in Figure 5, provides useful information about the location of the gas, trapped beneath the BSR. The seal 190 formed by GHs could be impermeable. At the landward termination of the GHSZ, the observed seismic 191 hyperbola and deformation zone in the surficial sedimentary layers suggest gas migration or the presence of 192 GHs close to the seafloor (Fig. 5-Inset). 
194 Theoretically determined phase equilibria allow to distinguish natural GHs from water ice, and can therefore

195 be used to calculate the temperature and pressure at which hydrates form from a given gas composition 196 (Sloan and Koh, 2007). The variations of water column temperature, pore pressure and geothermal gradient 197 affect the thickness of the GHSZ.

198 Seafloor temperature was considered to be $8.9{ }^{\circ} \mathrm{C}$ at $850 \mathrm{~m}$ water depth, determined by Sippican 199 measurements during GHASS cruise. A hydrostatic pore-pressure gradient of $0.1 \mathrm{bar} / \mathrm{m}$ was assumed to 200 calculate the depth scale (Kvenvolden, 1993). The geothermal gradient was measured with 7 temperature 201 sensors welded at regular intervals along a $12 \mathrm{~m}$ long core barrel. The geothermal gradient considered in 202 this study is $24.5^{\circ} \mathrm{C} / \mathrm{km}$. The composition of the gas enclathrated in hydrate form is a primordial parameter 203 to estimate the boundaries of GHSZ (Sloan, 2003). It is known that the main component of gas from the 204 Black Sea hydrates is $\mathrm{CH}_{4}$ (93.3-99.7\%: Vassilev and Dimitrov, 2003). As Poort et al. (2005) did, we 205 assumed a composition of $100 \%$ methane for the composition of the hydrates (Judd et al., 2002), but heavier 206 hydrocarbons could be present and would shift the hydrate stability curve towards higher temperatures 207 (Sloan and Koh, 2007).

208 The calculation of the GH stability curve is complicated because it is usually performed for a system 209 composed of water with a constant concentration of salt ( 0 psu to $>35 \mathrm{psu})$. In the study area, Soulet et al. 210 (2010) show a gradual fall in salinity from 21.9 psu at the seafloor level to near 2 psu at around 28 mbsf. In 211 the case presented here (Fig. 6), we make the calculation using a salinity of 22 psu for the water column $212(850 \mathrm{~m})$, a gradual fall of the salinity for the uppermost $28 \mathrm{~m}$ of sediment (the salinity of $22 \mathrm{psu}$ at the 213 seafloor reaching 2 psu in sediment at $28 \mathrm{mbsf}$ ) and a constant salinity of 2 psu for the rest of sedimentary 214 column. The intersection of the GH stability curves with the water column temperature curve denotes the 215 minimum water depth at which GHs are stable for a given water depth (Fig. 6), while the intersection with 216 the geothermal gradient reveals the predicted base of the GHSZ (Kvenvolden, 1993).

217 The calculation to obtain a predicted GHSZ is made at different water depths. An example of the calculation 218 for a water column of $850 \mathrm{~m}$ is shown in Figure 6. For this example, the intersection of the GH stability 219 curves with the water column temperature curve at around $730 \mathrm{~m}$ indicates the water depth at which GHs 220 are stable in this location of the Black Sea. The thickness of the GHSZ is $200 \mathrm{~m}$. The predicted base of 221 GHSZ is in agreement with the depth of the BSR observed in the study area (215 mbsf at $850 \mathrm{~m}$ water depth: 222 Fig. 5). The minimum water depth where GHs begin to be stable is $660 \mathrm{~m}$ at around 20 mbsf and the 223 thickness of the GHSZ would be $20 \mathrm{~m}$. We theoretically find stable GHs at the seafloor starting from 720 m water depth towards deeper waters. 


\section{Discussion}

\subsection{Impact of geomorphology in free gas expulsion}

Overall, the distribution of gas flares observed in the water column of the study area are in agreement with the free gas areas defined in Popescu et al. (2007). However, in some cases, several gas flares are detected downward the areas defined in the literature: many gas flares are inside the BSR zone defined in (Popescu et al., 2006) close to the landward termination of the BSR (Fig. 7). The causes of this mismatch could be attributed to an evolution of the degassing zone in the water column over the last 10 years and/or to the variety of the data analysis. The free gas area described by Popescu et al. (2006) was derived from seismic data interpretation while our gas flare areas from analysis of acoustic data recently acquired. Indeed, the identification of seepage activity at continental margins, which is a relatively widespread phenomena (Judd and Hovland, 2007), is emphasized by the water column mapping and technological advances in the last decade (Dupré et al., 2015).

The distribution of the gas seeps in the Romanian sector of the Black Sea coincides in most cases with the presence at the seafloor of sediment deformation features. $96 \%$ of the gas flares are located above canyons (Fig. 7C), landslides (Figs. 3C, 7A), pockmarks (Figs. 3B, 7B), and fault/ crest line (Fig. 3A). These observations and interpretations coincide with: (1) the recent analysis made in the Sea of Marmara where it was demonstrated that gas emissions in the water column are spatially controlled by fault and fracture networks in connection with the Main Marmara Fault system (Dupré et al., 2015); (2) several studies offshore California showing active seeps right above a vertically faulted and fractured region along the walls of the Monterey Canyon (Barry et al., 1996; Paull et al., 2005); and (3) previous studies in the Dnepr paleodelta (northwestern Black Sea), where seeps generally occur in association with pockmarks on the continental shelf, along crests of sedimentary ridges, canyon flanks and near submarine landslides on the continental slope (Naudts et al., 2006). Studies about the geomorphological control of the distribution of gas seepages finally show they follow the same pattern as the control of the distribution of pockmarks. Studies published during the last 20 years have demonstrated that the spatial organization of pockmarks (seafloor deformation due to fluid expulsion) may be the result of fluid seepage from underlying sedimentary structures such as fault systems (Pilcher and Argent, 2007), channels (Gay et al., 2003), mud volcanoes, mud diapirs, glaciogenic deposits (Forwick et al., 2009), and mass transport deposits (Riboulot et al., 2013).

253 The spatial distribution of pockmarks suggests that all the discontinuities within the sedimentary column 254 represent potential drains for fluid flow, and that simple diffusion through the sediments cannot explain the 255 observed pattern of fluid expulsion. The spatial distribution of a large proportion of the gas flares in the study area seems to be associated with gas contained in underlying sediment using discontinuities formed by landsliding. The discontinuities resulted from mass wasting processes inside and outside the canyons are 
et al. (2013) demonstrated in the Niger delta where a buried landslide controls the distribution of the seafloor

260 pockmarks.

261 4.2. Impact of Gas Hydrates Stability Zone in free gas expulsion and sedimentary deformation?

262 We observed only 26 gas seeps of the 1409 detected in the study area really inside the GHSZ (Figs. 2, 3A,

263 7). They are right above a crest line that represents $2 \%$ of the whole gas seeps detected in the study area.

264 We interpret the crest line as the seafloor evidence of the presence of a fault affecting the underlying 265 sedimentary sediments. If this is the case, as Gay et al. (2006) suggest in the Lower Congo Basin, we suppose 266 the fluids accumulate under the base of the hydrate stability zone form a layer of free gas and the generation 267 of excess pore fluid pressure in the free gas accumulation leads to the release of fluids along faults of the 268 highly faulted interval responsible of the presence of free gas at the seafloor and in the water column.

269 Due to the concentration of gas seepages outside and at the landward termination of the GHSZ (98\% of the 270 whole degassing site) and the seismic anomalies observed under the BSR (Fig. 5), we suggest that the 271 presence of GHs at the base of GHSZ constitutes an impermeable caprock over an accumulation of free gas. 272 Indeed, GHs may fill pore spaces and reduce sediment permeability, so that in some cases hydrate-bearing 273 sediment may act as seal and result in gas traps (Max and Dillon 1998). This interpretation is in agreement 274 with the observations of Naudts et al. (2006) in the Dnepr paleo-delta area where the depth limit for 99.5\% 275 of the detected seeps coincides with the phase boundary of pure methane hydrate at $725 \mathrm{~m}$ water depth. 276 They suggest GHs play the role of buffer for the upward migration of methane gas and thus prevent seepage 277 of methane bubbles into the water column as it was proposed by Popescu et al. (2007) in the Danube Deep278 Sea Fan area and by Westbrook et al. (2009) in the West Spitsbergen margin. This process may explain the 279 lack of deformation of the overlying sedimentary layers (Fig. 5), the absence of gas flares in the water 280 column inside the GHSZ and the possible deformation at the landward termination of the GHSZ around the 281 small mounts.

282 Indeed, the analysis of the seafloor morphology inside the GHSZ combined with the seismic stratigraphy 283 provide useful information on the impact of GHs on sedimentary deformation. The seafloor deformation, 284 characteristics of the features named "gas-hydrate pockmarks" and described around the world (Macelloni 285 et al., 2012; Riboulot et al., 2016; Simonetti et al., 2013; Sultan et al., 2014), are not observed in the study 286 area. GH pockmarks characterize seafloors where GHs are present in the shallow sedimentary layers. 287 Sediment deformation at the landward termination of the BSR may be induced by GH dynamics as it was 288 described in the Niger delta by Riboulot et al. (2016) and Sultan et al. (2014). The presence of GHs close to 289 the seafloor generate a disturbance of the sedimentary deposits and the loss of their original sedimentary 290 structures. The small mounts, observed around this area and mentioned in Figures 2 and 5, rather seem to 
291 be the result of an inherited morphology from the compressive bulge of an underlying landslide without 292 implication of GH dynamics.

293 It may be noted that several headwall scarps are observed at around $650 \mathrm{~m}$ water depth. The landward 294 termination of the GHSZ coincide with these escarpments. 35\% of the gas seeps observed in the water 295 column are localized right above scarps at the boundary with the GHSZ. It suggests GH dynamics may have 296 an implication in sediment failure as it was interpreted by Westbrook et al. (2009). Further investigation 297 will be needed to confirm this hypothesis.

\section{Conclusions}

299 The continental slope morphology of the Romanian sector of the Black Sea is incised by several landslides

300 inside and outside canyons. It is a complex study area presenting sedimentary processes such as seafloor 301 erosion and instability, mass wasting, formation of GHs, fluid migration, gas escape, where the imprint of 302 geomorphology seems to dictate the location where gas seep occurs. We have detected 1409 active seeps 303 within the $1200 \mathrm{~km}^{2}$ of the shelf and slope north-east of the Danube canyon. Most gas seeps (96\%) are not 304 randomly distributed in this area. They occur along canyon flanks, scarps, crest lines, faults and in 305 association with pockmarks and mounts.

306 Moreover the depth limit for $98 \%$ of the gas seeps coincides with the predicted landward termination of 307 GHSZ. This suggest GHs formed at the base of the GHSZ act as an effective seal preventing gas to reach 308 the seafloor and the water column. The extent and the dynamics of GHs have a probable impact on the 309 sedimentary destabilization observed at the seafloor and the stability of the GHs is dependent on the salinity 310 gradient through the sedimentary column and thus on the Black Sea recent geological history.

\section{Acknowledgment}

312 The support by officers and crew during the GHASS cruise on board R/V Pourquoi Pas ? (2015) is greatly 313 appreciated, as is the dedication of the Genavir and Ifremer technical staff during the cruise. We thank 314 sincerely Alison Chalm for her revision of the English language.

\section{References}

316 Bangs, N.L.B., Musgrave, R.J., Tréhu, A.M., 2005. Upward shifts in the southern Hydrate Ridge gas hydrate 317 stability zone following postglacial warming, offshore Oregon. Journal of Geophysical Research: Solid 318 Earth 110.

319 Barry, J.P., Greene, H.G., Orange, D.L., Baxter, C.H., Robison, B.H., Kochevar, R.E., Nybakken, J.W., 320 McHugh, C.M., 1996. Biologic and geologic characteristics of cold seeps in Monterey Bay, California. Deep 321 Sea Research Part I: Oceanographic Research Papers 43, 1739-1762. 
Bull, S., Cartwright, J., Huuse, M., 2009. A review of kinematic indicators from mass-transport complexes using 3D seismic data. Marine and Petroleum Geology 26, 1132-1151.

Constantinescu, A.M., Toucanne, S., Dennielou, B., Jorry, S.J., Mulder, T., Lericolais, G., 2015. Evolution of the Danube Deep-Sea Fan since the Last Glacial Maximum: new insights into Black Sea water-level fluctuations. Marine Geology 367, 50-68.

Crémière, A., Lepland, A., Chand, S., Sahy, D., Condon, D.J., Noble, S.R., Martma, T., Thorsnes, T., Sauer, S., Brunstad, H., 2016. Timescales of methane seepage on the Norwegian margin following collapse of the Scandinavian Ice Sheet. Nature Communications 7.

Davis, A.M., 1992. Shallow gas: an overview. Continental Shelf Research 12, 1077-1079.

Demirbas, A., 2009. Methane from gas hydrates in the black sea. Energy Sources, Part A: Recovery, Utilization, and Environmental Effects 32, 165-171.

Dillon, W.P., Paull, C.K., 1983. Marine gas hydrates, II. Geophysical evidence. Natural Gas Hydrates: Properties, Occurrences, and Recovery: Woburn, MA (Butterworth), 73-90.

Dimitrov, L., 2002. Contribution to atmospheric methane by natural seepages on the Bulgarian continental shelf. Continental Shelf Research 22, 2429-2442.

Dupré, S., Scalabrin, C., Grall, C., Augustin, J.M., Henry, P., Şengör, A.M., Görür, N., Çağatay, M.N., Géli, L., 2015. Tectonic and sedimentary controls on widespread gas emissions in the Sea of Marmara: Results from systematic, shipborne multibeam echo sounder water column imaging. Journal of Geophysical Research: Solid Earth 120, 2891-2912.

Forwick, M., Baeten, N.J., Vorren, T.O., 2009. Pockmarks in Spitsbergen fjords. Norwegian Journal of Geology 89, 65-77.

Garcia-Gil, S., Vilas, F., Garcia-Garcia, A., 2002. Shallow gas features in incised-valley fills (Ria de Vigo, NW Spain): a case study. Continental Shelf Research 22, 2303-2315.

Gay, A., Lopez, M., Berndt, C., Seranne, M., 2007. Geological controls on focused fluid flow associated with seafloor seeps in the Lower Congo Basin. Marine Geology 244, 68-92.

Gay, A., Lopez, M., Cochonat, P., Sultan, N., Cauquil, E., Brigaud, F., 2003. Sinuous pockmark belt as indicator of a shallow buried turbiditic channel on the lower slope of the Congo Basin, West African Margin. Geological Society, London, Special Publications 216, 173-189.

Gay, A., Lopez, M., Cochonat, P., Séranne, M., Levaché, D., Sermondadaz, G., 2006. Isolated seafloor pockmarks linked to BSRs, fluid chimneys, polygonal faults and stacked Oligocene-Miocene turbiditic palaeochannels in the Lower Congo Basin. Marine Geology 226, 25-40.

Ginsburg, G.D., 1998. Gas hydrate accumulation in deep-water marine sediments. Geological Society, London, Special Publications 137, 51-62.

Gorman, A.R., Holbrook, W.S., Hornbach, M.J., Hackwith, K.L., Lizarralde, D., Pecher, I., 2002. Migration of methane gas through the hydrate stability zone in a low-flux hydrate province. Geology 30, 327-330.

Greinert, J., McGinnis, D.F., Naudts, L., Linke, P., De Batist, M., 2010. Atmospheric methane flux from bubbling seeps: Spatially extrapolated quantification from a Black Sea shelf area. Journal of Geophysical Research: Oceans 115.

Heggland, R., 1997. Detection of gas migration from a deep source by the use of exploration 3D seismic data. Marine Geology 137, 41-47.

Hempel, P., Spiess, V., Schreiber, R., 1994. Expulsion of shallow gas in the Skagerrak - evidence from subbottom profiling, seismic, hydroacoustical and geochemical data. Estuarine, Coastal and Shelf Science 38, 583-601.

Hester, K.C., Brewer, P.G., 2009. Clathrate hydrates in nature. Annual review of marine science 1, 303327.

Holbrook, W.S., Hoskins, H., Wood, W.T., Stephen, R.A., Lizarralde, D., 1996. Methane hydrate and free gas on the Blake Ridge from vertical seismic profiling. Science 273, 1840.

Hustoft, S., Bünz, S., Mienert, J., 2010. Three-dimensional seismic analysis of the morphology and spatial distribution of chimneys beneath the Nyegga pockmark field, offshore mid-Norway. Basin Research 22, 465-480. 
Hustoft, S., Mienert, J., Bünz, S., Nouzé, H., 2007. High-resolution 3D-seismic data indicate focussed fluid

106.

Ion, G., Lericolais, G., Nouzé, H., Panin, N., Ion, E., 2002. Seismo-acoustic evidence of gases in sedimentary edifices of the paleo-Danube realm, pp. 91-95.

Jones, A.T., Greinert, J., Bowden, D.A., Klaucke, I., Petersen, C.J., Netzeband, G.L., Weinrebe, W., 2010. Acoustic and visual characterisation of methane-rich seabed seeps at Omakere Ridge on the Hikurangi Margin, New Zealand. Marine Geology 272, 154-169.

Judd, A., Hovland, M., 2007. Seabed fluid flow. The impact on geology, biology and the marine environment. Cambridge University, Cambridge.

Judd, A.G., Hovland, M., 1992. The evidence of shallow gas in marine sediments. Continental Shelf Research 12, 1081-1095.

Judd, A.G., Hovland, M., Dimitrov, L.I., Garcia Gil, S., Jukes, V., 2002. The geological methane budget at continental margins and its influence on climate change. Geofluids 2, 109-126.

King, L.H., MacLean, B., 1970. Pockmarks on the Scotian shelf. Geological Society of America Bulletin 81, 3141-3148.

Kvenvolden, K.A., 1993. Gas hydrates-geological perspective and global change. Reviews of Geophysics 31, 173-173.

Lüdmann, T., Wong, H.K., Konerding, P., Zillmer, M., Petersen, J., Flüh, E., 2004. Heat flow and quantity of methane deduced from a gas hydrate field in the vicinity of the Dnieper Canyon, northwestern Black Sea. Geo-Marine Letters 24, 182-193.

Macelloni, L., Simonetti, A., Knapp, J.H., Knapp, C.C., Lutken, C.B., Lapham, L.L., 2012. Multiple resolution seismic imaging of a shallow hydrocarbon plumbing system, Woolsey Mound, Northern Gulf of Mexico. Marine and Petroleum Geology 38, 128-142.

Mathys, M., Thießen, O., Theilen, F., Schmidt, M., 2005. Seismic characterisation of gas-rich near surface sediments in the Arkona Basin, Baltic Sea. Marine Geophysical Researches 26, 207-224.

McGinnis, D.F., Greinert, J., Artemov, Y., Beaubien, S.E., Wüest, A., 2006. Fate of rising methane bubbles in stratified waters: How much methane reaches the atmosphere? Journal of Geophysical Research: Oceans 111.

Merey, S., Sinayuc, C., 2016. Investigation of gas hydrate potential of the Black Sea and modelling of gas production from a hypothetical Class 1 methane hydrate reservoir in the Black Sea conditions. Journal of Natural Gas Science and Engineering 29, 66-79.

Mert Küçük, H., Dondurur, D., Özel, Ö., Sinayuç, Ç., Merey, S., Parlaktuna, M., Çifçi, G., Gas and Gas Hydrate Potential Offshore Amasra, Bartin and Zonguldak and Possible Agent for Multiple BSR Occurrence, p. 10310.

Naudts, L., De Batist, M., Greinert, J., Artemov, Y., 2009. Geo-and hydro-acoustic manifestations of shallow gas and gas seeps in the Dnepr paleodelta, northwestern Black Sea. The Leading Edge 28, 10301040 .

Naudts, L., Greinert, J., Artemov, Y., Beaubien, S.E., Borowski, C., De Batist, M., 2008. Anomalous seafloor backscatter patterns in methane venting areas, Dnepr paleo-delta, NW Black Sea. Marine Geology 251, 253-267.

Naudts, L., Greinert, J., Artemov, Y., Staelens, P., Poort, J., Van Rensbergen, P., De Batist, M., 2006. Geological and morphological setting of 2778 methane seeps in the Dnepr paleo-delta, northwestern Black Sea. Marine Geology 227, 177-199.

Netzeband, G.L., Krabbenhöft, A., Zillmer, M., Petersen, C.J., Papenberg, C., Bialas, J., 2010. The structures beneath submarine methane seeps: seismic evidence from Opouawe Bank, Hikurangi Margin, New Zealand. Marine Geology 272, 59-70.

Nisbet, E.G., Piper, D.J.W., 1998. Giant submarine landslides. Nature 392, 329-330.

Overmann, J., Manske, A.K., 2006. Anoxygenic phototrophic bacteria in the Black Sea chemocline, Past and Present Water Column Anoxia. Springer, pp. 523-541. 
Paull, C.K., Schlining, B., Ussler, W., Paduan, J.B., Caress, D., Greene, H.G., 2005. Distribution of

Paull, C.K., Ussler, W., Borowski, W.S., Spiess, F.N., 1995. Methane-rich plumes on the Carolina continental rise: associations with gas hydrates. Geology 23, 89-92.

Pilcher, R., Argent, J., 2007. Mega-pockmarks and linear pockmark trains on the West African continental margin. Marine Geology 244, 15-32.

Poort, J., Vassilev, A., Dimitrov, L., 2005. Did postglacial catastrophic flooding trigger massive changes in the Black Sea gas hydrate reservoir? Terra Nova 17, 135-140.

Popescu, I., De Batist, M., Lericolais, G., Nouzé, H., Poort, J., Panin, N., Versteeg, W., Gillet, H., 2006. Multiple bottom-simulating reflections in the Black Sea: potential proxies of past climate conditions. Marine Geology 227, 163-176.

Popescu, I., Lericolais, G., Panin, N., De Batist, M., Gillet, H., 2007. Seismic expression of gas and gas hydrates across the western Black Sea. Geo-Marine Letters 27, 173-183.

Popescu, I., Lericolais, G., Panin, N., Normand, A., Dinu, C., Le Drezen, E., 2004. The Danube submarine canyon (Black Sea): morphology and sedimentary processes. Marine Geology 206, 249-265.

Riboulot, V., Cattaneo, A., Sultan, N., Garziglia, S., Ker, S., Imbert, P., Voisset, M., 2013. Sea-level change and free gas occurrence influencing a submarine landslide and pockmark formation and distribution in deepwater Nigeria. Earth and Planetary Science Letters 375, 78-91.

Riboulot, V., Sultan, N., Imbert, P., Ker, S., 2016. Initiation of gas-hydrate pockmark in deep-water Nigeria: Geo-mechanical analysis and modelling. Earth and Planetary Science Letters 434, 252-263.

Ross, D.A., Degens, E.T., MacIlvaine, J., 1970. Black Sea: recent sedimentary history. Science 170, 163165.

Schroot, B.M., Klaver, G.T., Schüttenhelm, R.T.E., 2005. Surface and subsurface expressions of gas seepage to the seabed - examples from the Southern North Sea. Marine and Petroleum Geology 22, 499515.

Schroot, B.M., Schuttenhelm, R.T.E., 2003. Expressions of shallow gas in the Netherlands North Sea. Netherlands Journal of Geosciences 82, 91-106.

Shipley, T.H., Houston, M.H., Buffler, R.T., Shaub, F.J., McMillen, K.J., Ladd, J.W., Worzel, J.L., 1979. Seismic evidence for widespread possible gas hydrate horizons on continental slopes and rises. AAPG bulletin 63, 2204-2213.

Simonetti, A., Knapp, J.H., Sleeper, K., Lutken, C.B., Macelloni, L., Knapp, C.C., 2013. Spatial distribution of gas hydrates from high-resolution seismic and core data, Woolsey Mound, Northern Gulf of Mexico. Marine and Petroleum Geology 44, 21-33.

Sloan, E.D., 2003. Fundamental principles and applications of natural gas hydrates. Nature 426, 353-363. Sloan, E.D., Koh, C., 2007. Clathrate hydrates of natural gases. CRC press.

Solomon, E.A., Kastner, M., MacDonald, I.R., Leifer, I., 2009. Considerable methane fluxes to the atmosphere from hydrocarbon seeps in the Gulf of Mexico. Nature Geoscience 2, 561-565.

Soulet, G., Delaygue, G., Vallet-Coulomb, C., Böttcher, M.E., Sonzogni, C., Lericolais, G., Bard, E., 2010. Glacial hydrologic conditions in the Black Sea reconstructed using geochemical pore water profiles. Earth and Planetary Science Letters 296, 57-66.

Sultan, N., Bohrmann, G., Ruffine, L., Pape, T., Riboulot, V., Colliat, J.L., De Prunelé, A., Dennielou, B., Garziglia, S., Himmler, T., 2014. Pockmark formation and evolution in deep water Nigeria: Rapid hydrate growth versus slow hydrate dissolution. Journal of Geophysical Research: Solid Earth 119, 2679-2694.

Taylor, M.H., Dillon, W.P., Pecher, I.A., 2000. Trapping and migration of methane associated with the gas hydrate stability zone at the Blake Ridge Diapir: new insights from seismic data. Marine Geology 164, 7989.

Tréhu, A.M., Flemings, P.B., Bangs, N.L., Chevallier, J., Gràcia, E., Johnson, J.E., Liu, C.S., Liu, X., Riedel, M., Torres, M.E., 2004. Feeding methane vents and gas hydrate deposits at south Hydrate Ridge. Geophysical Research Letters 31.

Vassilev, A., Dimitrov, L., 2003. Model evaluation of the Black Sea gas hydrates. Comptes Rendus de l'Academie bulgare des Sciences 56, 3-15. 
Westbrook, G.K., Thatcher, K.E., Rohling, E.J., Piotrowski, A.M., Pälike, H., Osborne, A.H., Nisbet, E.G., Spitsbergen continental margin. Geophysical Research Letters 36.

Winguth, C., Wong, H.K., Panin, N., Dinu, C., Georgescu, P., Ungureanu, G., Krugliakov, V.V., Podshuveit, V., 2000. Upper Quaternary water level history and sedimentation in the northwestern Black Sea. Marine Geology 167, 127-146.

Wong, H.K., Panin, N., Dinu, C., Georgescu, P., Rahn, C., 1994. Morphology and post-Chaudian (Late Pleistocene) evolution of the submarine Danube fan complex. Terra Nova 6, 502-511.

Yefremova, A.G., Zhizhchenko, B.P., 1974. Gas hydrate occurrences in offshore deposits. DAN SSSR (Proceedings of the USSR Academy of Sciences) 214, 1179-1181.

Zillmer, M., Flueh, E.R., Petersen, J., 2005. Seismic investigation of a bottom simulating reflector and quantification of gas hydrate in the Black Sea. Geophysical Journal International 161, 662-678.

Zubakov, V.A., 1988. Climatostratigraphic scheme of the Black Sea Pleistocene and its correlation with the oxygen-isotope scale and glacial events. Quaternary Research 29, 1-24.

\section{Figure captions}

Figure 1: Bathymetric map, acquired during the 2015 GHASS cruise, showing the study area with the location of seismic profiles. Fine grey lines show the multibeam navigation where the presence of free gas in the water column was searched. The continental slope is dissected by the Danube canyon and the Canyons 1 and 2 with several submarine landslide scars along canyon flanks.

Figure 2: Geomorphologic map of the study area with superposed: free gas and BSR areas detailed in Popescu et al. (2006, 2007), cartography of the gas bubbles acoustically detected in the water column, and the predicted landward limit of the predicted GHSZ (bold black line). The modern landward termination of the GHSZ correspond to the 660 mbsl bathymetric contour.

Figure 3: The 3D views of the seafloor and water column (GLOBE software (C) Ifremer), with processed polar echograms, show (A) a crest line inside the GHSZ, (B) a pockmark and (C) a headwall scarp. The acoustic anomalies recorded in the water column are echoes caused by escaping gas bubbles through the seafloor. The acoustic imprint of the plumes almost reaches a height of $300 \mathrm{~m}$ above the seafloor. The 3 examples are localized on the figure 1.

Figure 4: Seismic reflection profile Bla 1-8 (BLASON cruise). Across the shelf break and the upper slope within the free gas area defined in Popescu et al. (2007; location in Fig. 1). The close up views (A, B and C) show how the occurrence of free gas affects seismic data. The most apparent free gas zones are identified under a mass transport complex (in orange). Several free gas zones coincide with the presence of gas chimneys and pockmarks (A and B) while when the seafloor depth is deeper we have a lack of seafloor fluid features. The gas seems to be trapped under the MTC. 
509 negative polarity reflector associated to an increase in the attenuation and amplitude anomalies (seismic 510 signature of the free gas - green arrows). Within the predicted GHSZ, right above the BSR, we do not 511 observed seismic signature of the presence of free gas. The free gas seems to be trapped under the MTC. 512 The black rectangle indicates the area of inset. The inset highlights the location of the supposed GH 513 occurrence within a deformed sedimentary layers at the landward termination of the BSR.

514 Figure 6: Gas hydrate stability using pure s-I methane hydrate and the water column $(\mathrm{S}=22 \mathrm{psu})$ and 515 porewater ( $\mathrm{S}=2$; in depth higher than $25 \mathrm{mbsf}$ ) salinities. For this example used to illustrate the calculation 516 (Seafloor: $850 \mathrm{~m}$ water depth), the minimum water depth where GHs are stable is $720 \mathrm{mbsl}$. The bottom 517 water temperature used is $8.9^{\circ} \mathrm{C}$. For the regional observed geothermal gradients of $24.5^{\circ} \mathrm{C} / \mathrm{km}$, the base 518 of GHSZ is 200 mbsf. These results are calculated in 2D and change with depth of the seafloor due to the 519 evolution of the salinity within the sediment.

520 Figure 7: Dip map derived from the bathymetric map of the study area with superimposed (1) 521 geomorphological features/zones, (2) limits of the GHSZ and (3) presence of measured gas bubbles in the 522 water column. Red marks stand for water column acoustic anomalies recorded from Sept $1^{\text {st }}$ to $15^{\text {th }}, 2015$. 523 The white rectangles indicate the areas of inset. The insets highlight key zones showing the spatial 524 distribution of bubbles along headwall scarps (A), pockmarks - destabilized zones (B), canyon flanks (C), 525 and the landward termination of the GHSZ (D). 


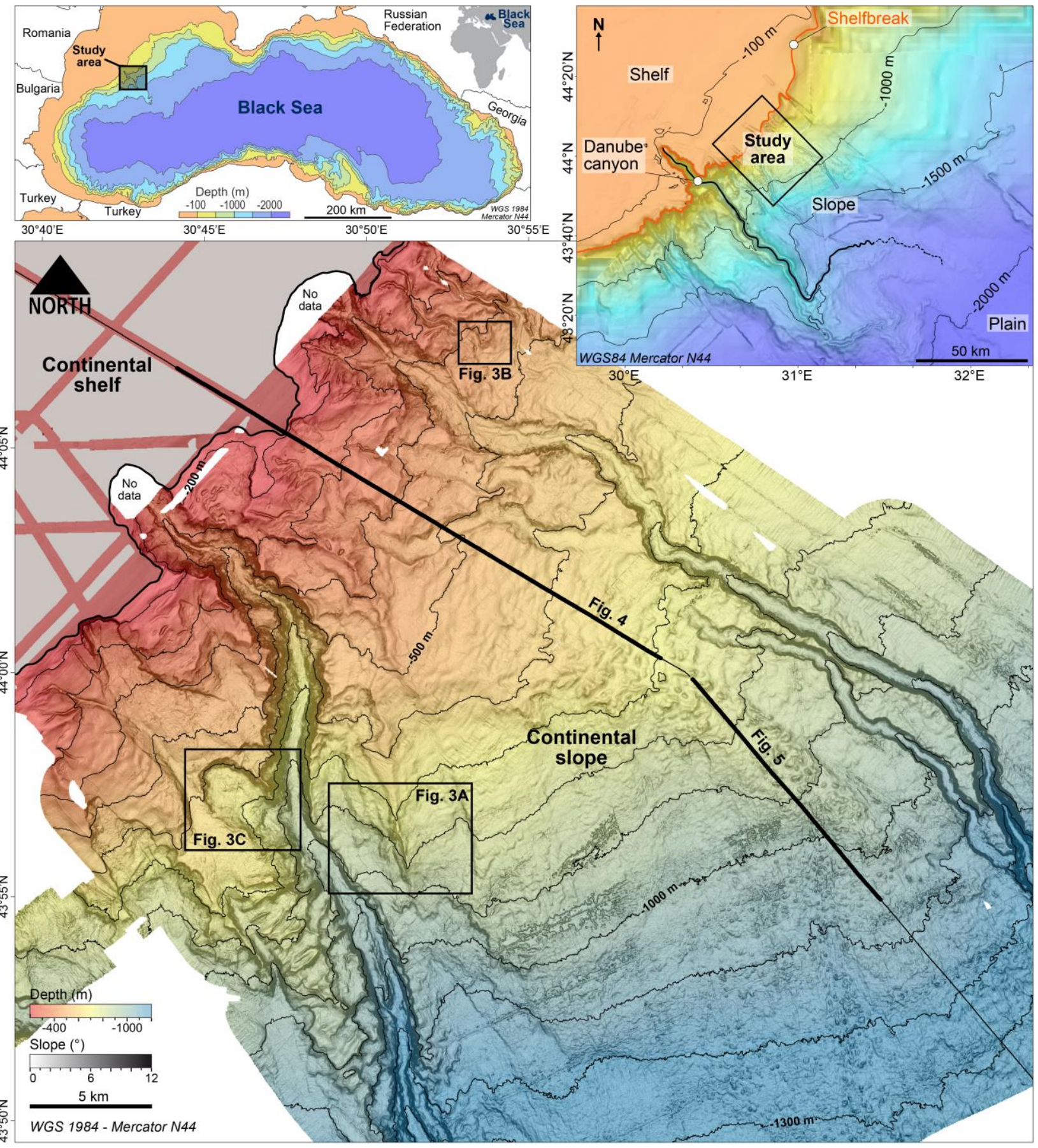




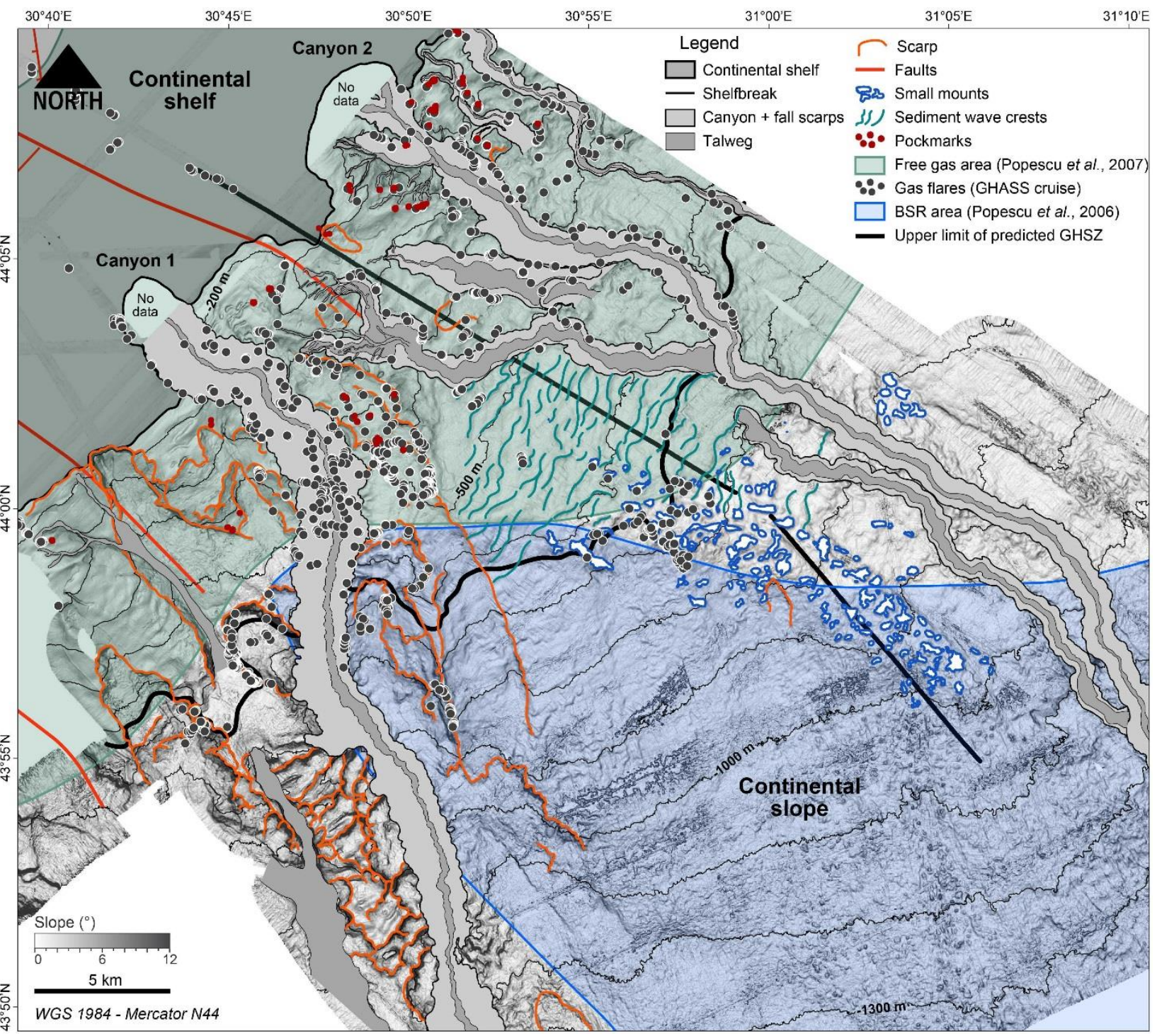



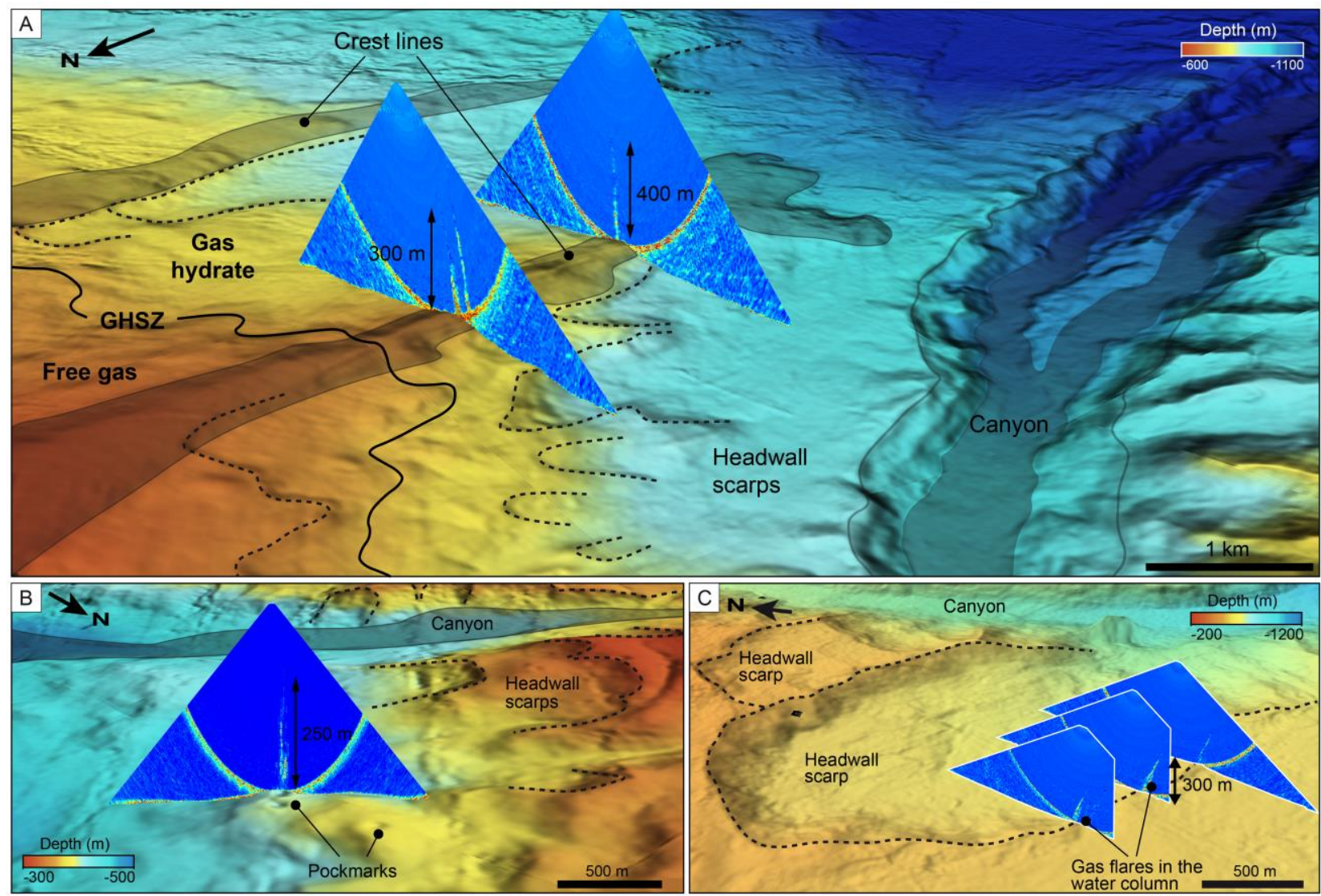

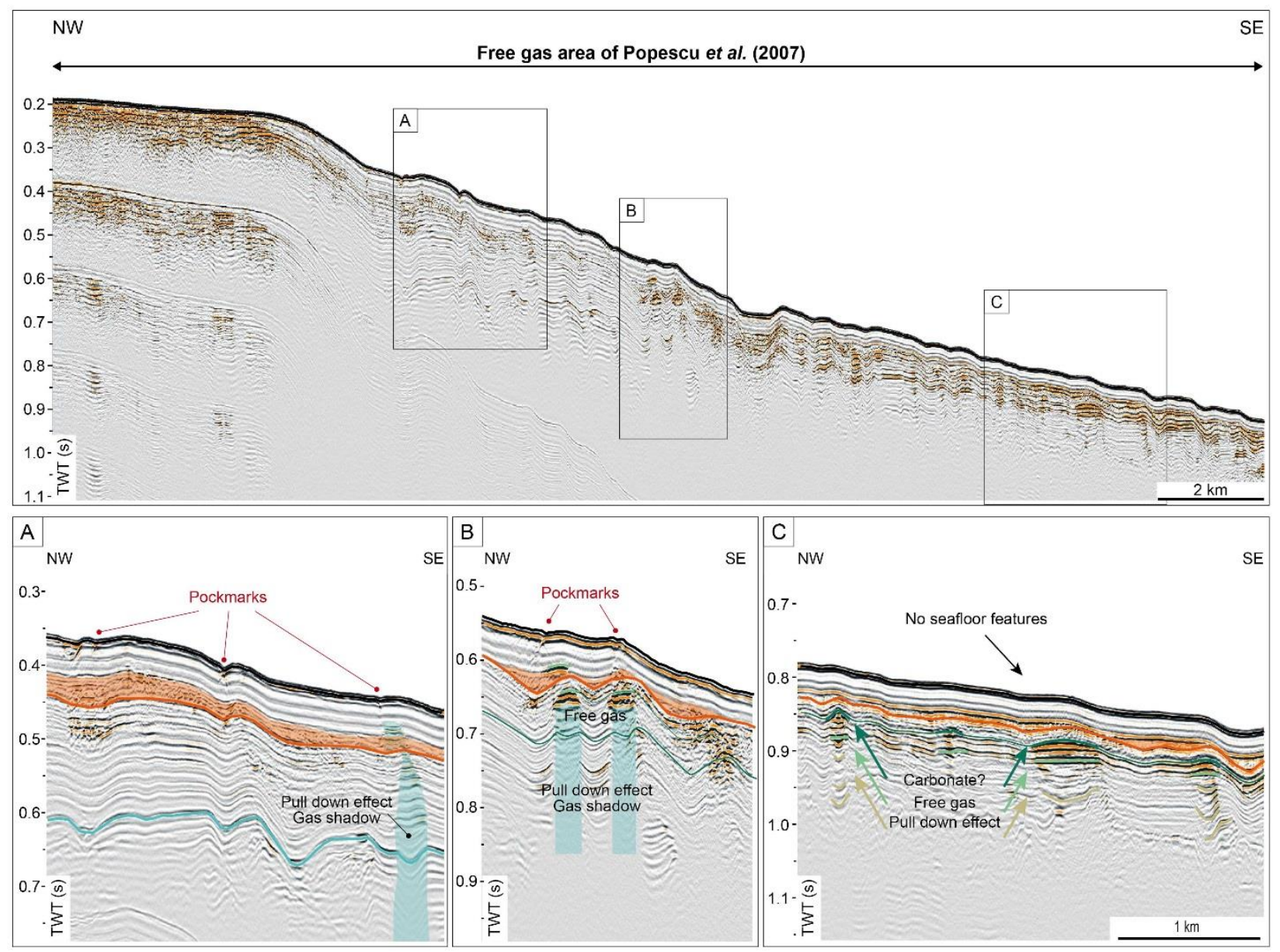


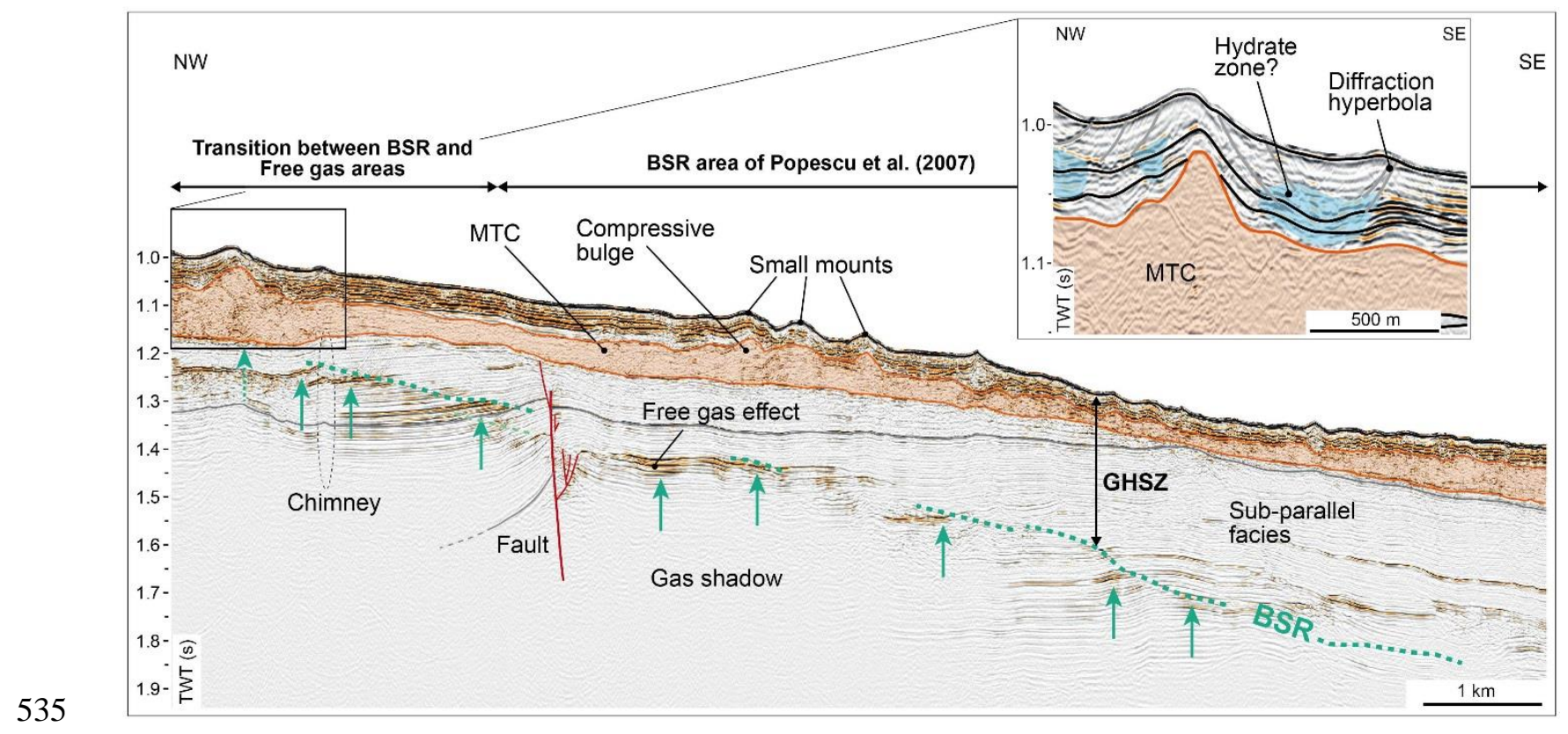




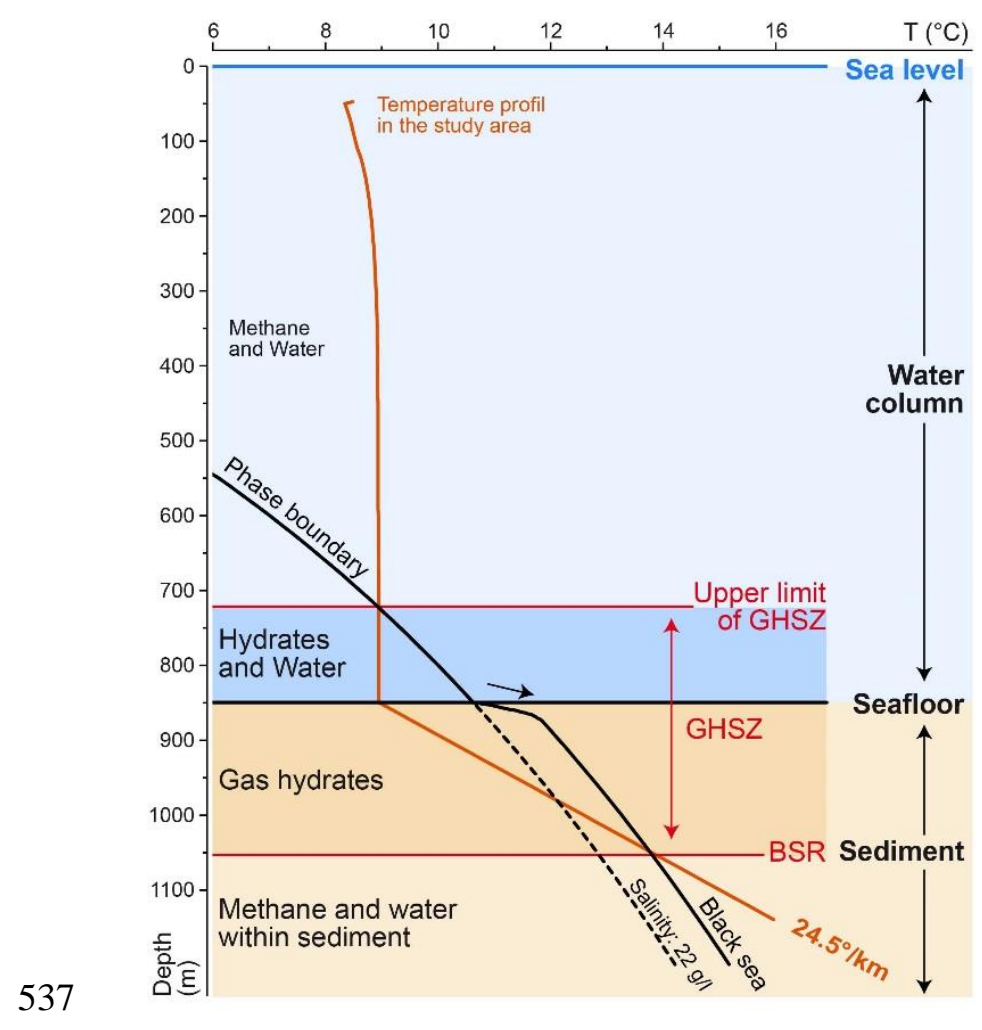




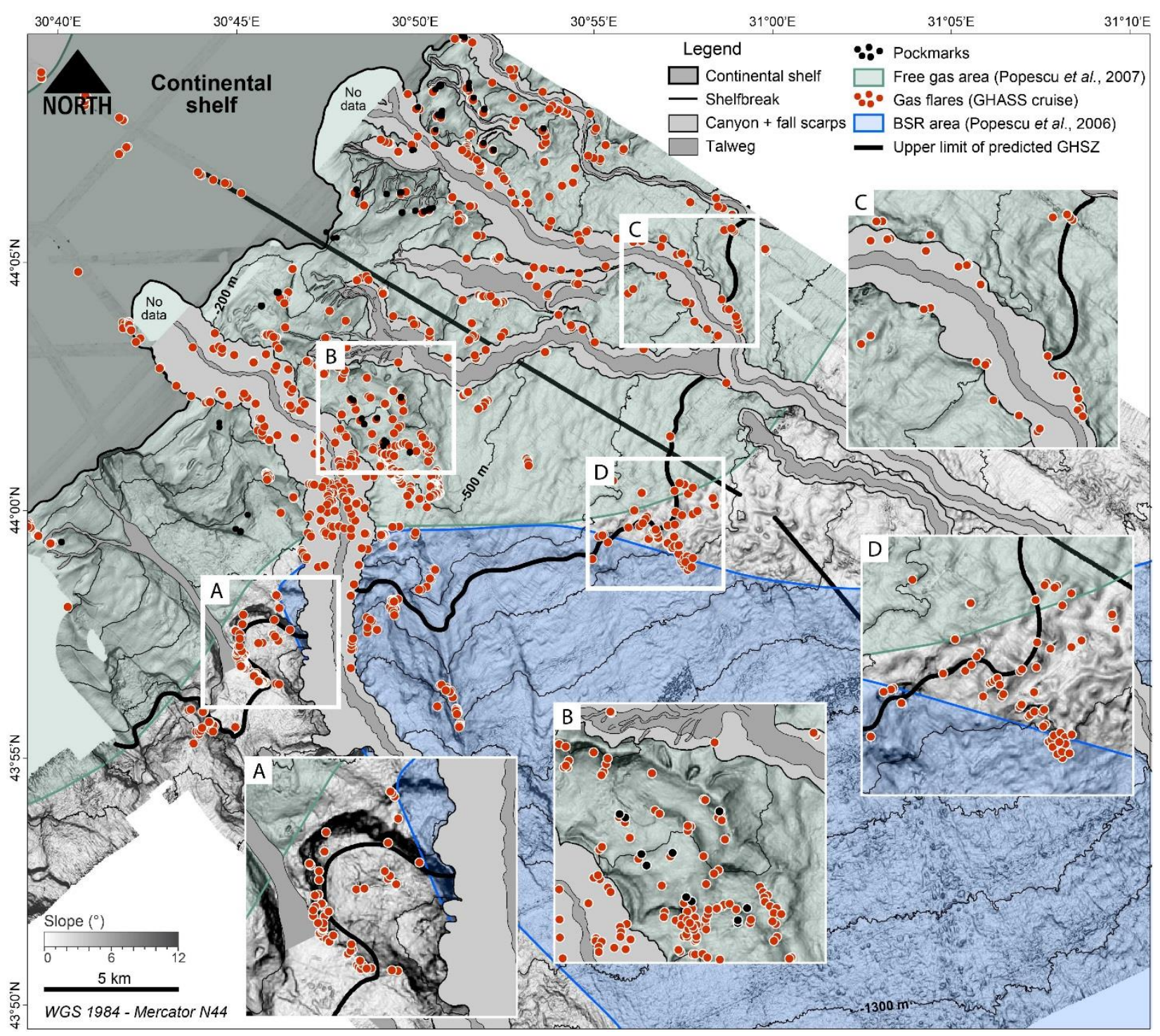

